\title{
Interoperatability of Mobile Number Portability in South West Nigeria
}

\author{
Oloja, S.V \\ Achievers Uni, Owo, Ondo \\ State, Nigeria
}

\author{
kuboye B.M \\ Computer Sci, FUTA Ondo \\ State, Nigeria
}

\author{
Chukwuma, I.O \\ Achievers Uni, Owo, Ondo \\ State, Nigeria
}

\begin{abstract}
Mobile number portability (MNP) is a telecommunication network property which allows subscribers to retain their mobile phone numbers when changing from one network provider to another. It serves as the yardstick for increasing competition and for improving quality of service among network providers, because subscribers have the freedom to migrate from one network provider to another. In the past, quality of service was poor due to low transparency from the end of the network providers but with the introduction of MNP, there will be check and balances among the network providers as each of them are trying to woo the subscribers to its network.

This paper explores the benefits of MNP and some of its applications in the telecommunication industry. In this work, some arising issues concerning MNP were put together in a questionnaire and copies were administered to respondents of different sex, ages, locations and networks across six states in south west Nigeria. Thereafter, some hypotheses relevant to MNP were formulated for test based on some factors influencing the success of MNP. These hypotheses were later analyzed and tested using chi-square. The results of our analysis show that there is no significant impact of social influence on mobile number portability scheme among mobile users. That means there is skepticism of acceptance among the elite group users but with increase on quality of service and reduction in tariff thus this acceptability will ratio increase.
\end{abstract}

\section{Keywords}

MNP, Subscribers, Chi-square, Telecommunication, Hypotheses, Questionnaire.

\section{INTRODUCTION}

Mobile number portability allows a mobile subscriber to switch operators without changing their mobile number.

Mobile Number Portability (MNP) requires that mobile telephone customers can keep their telephone numbers when switching from one provider to another. In the absence of MNP, customers have to give up their provider pricing platform and must accept a new one when they switch operators. Prior to the introduction of MNP, the subscribers that wish to change operator have to buy new sin card of the intending network operator thereby changing the mobile number. With MNP the subscribers need only to switch to the new network without changing their number. As a result, customers face switching costs associated with informing people about changing their numbers, printing new business cards, missing valuable calls from people that do not have the new numbers. Based on these considerations, many regulatory authorities have imposed mandatory MNP so as to reduce customers' switching costs, attempting to make mobile telecommunications more competitive [2].
Number Portability will allow subscribers to change their service providers while retaining their old mobile numbers. Portability is beneficial to the subscribers and increases the level of competition among service providers. Also rewarding service providers with the best customer service, network coverage, and quality of service [3].

Mobile Number Portability (MNP) was targeted for introduction in last quarter of 2011 but was not launched until 2013. This allows subscribers to port their numbers from one Mobile Network to another Mobile Network. NCC believes that the Nigeria's Mobile market has the newest generation of networks, that competition is already introduced; and that MNP will indirectly improve Quality of Service as the market competition matures. Now the competition in the air is fiercer. The companies have started paying attention to reducing the profit margins and are targeting on volume of business [7]. With mobile number portability scheme, customer can change his service provider without any worries. This has put a strong weapon in the hands of the subscribers. Earlier before 2012, the subscribers had to change the number by getting a new line and had to inform everyone about his new number. Due to this confusion many of the subscribers were afraid of switching the service providers. Now the reins are in the hands of the subscribers.

This research work helps to get the statistic and full record on the performance evaluation of inter-operability of mobile number portability in South West, Nigeria, educate people on how to use mobile number portability and evaluate interoperability in mobile number portability among different Network providers as they are wooing each subscribers to their network.

\subsection{Types of Mobile Number Portability}

Mobile number portability can be classified into four distinct categories. [4]

- Location Based Portability - Through this the user can port numbers between different geographical areas.

- $\quad$ Operator Based Portability - Through this the user ports its numbers from different service providers within the same circle.

- Service Based Portability - Through this the user can port numbers between CDMA to GSM or vice versa for the same operator.

- Convergence Based Portability - Through this the user can port its land line number to mobile telephony or vice versa [4]. 


\section{THEORETICAL CONSTRUCT/HYPOTHESES}

There are several factors that influence MNP among which are subscriber awareness, simplicity, speed and cost [5]. The hypotheses in this work are based on these factors. They are as follows.

$\mathbf{H}_{\mathbf{1}}$ : There is no significant impact of perceived switching barriers on mobile number portability scheme among mobile users.

$\mathbf{H}_{2}$ : There is no significant impact of perceived service fairness on mobile number portability scheme among mobile users.

$\mathbf{H}_{3}$ : There is no significant impact of experiences with current service provider on mobile number portability scheme among mobile users.

$\mathbf{H}_{4}$ : There is no significant impact of social influence on mobile number portability scheme among mobile users.

\section{RESEARCH METHODOLOGY}

This study is limited to the evaluation of the interoperability of MNP in the following GSM networks: Etisalat, Glo, MTN, and Airtel in the South West, Nigeria which includes states such as: Lagos, Ekiti, Ondo, Osun, Ogun and Oyo. 500 questionnaires were sampled across six states of the South West, Nigeria namely: Lagos, Ekiti, Ondo, Osun, Ogun and Oyo, using questionnaires. The questionnaires were distributed equally and simultaneously, to minimize a sampling bias that might arise from migration. Respondents were selected randomly from different parts of each of the states under consideration.

3.1 Tools for Data Collection: For primary data collection on mobile telecom carriers in Nigeria, a questionnaire containing 10 statements was used. Secondary data were collected from various sources like- Internet, books, newspapers, journals, business magazines etc.

3.2 Tools for Data Analysis: The data were tabulated in Excel sheets and analyzed by using Chi-square analysis to test the hypotheses.

3.3 Data Collection and Summary (Analysis of Responses) Table 1. to 2. and their descriptions are summaries of the survey data as provided by the respondents. 392 of the 500 questionnaires distributed across the six states of the South West, Nigeria were retrieved.

Table 1. Sex of Respondents

* 15 responses were invalid here due to no ticking

\begin{tabular}{|l|l|l|l|}
\hline Gender & Frequency & Percentage & $\begin{array}{l}\text { Cumulative } \\
\text { percentage }(\%)\end{array}$ \\
\hline Male & 170 & 45.0 & 45.0 \\
\hline Female & 207 & 55.0 & 100 \\
\hline Total & $377^{*}$ & 100 & - \\
\hline
\end{tabular}

From the table 1. Sex of Respondents has a 207 (55\%) of the respondents sampled were female, compared to the $170(45 \%)$ male shows that more females use mobile phones than males during our survey.
Table 2. Age Bracket of Respondents

\begin{tabular}{|c|c|c|c|}
\hline $\begin{array}{c}\text { Age } \\
\text { Declaration }\end{array}$ & Frequency & Percentage & $\begin{array}{c}\text { Cumulative } \\
\text { percentage } \\
(\%)\end{array}$ \\
\hline $\begin{array}{c}16-20 \\
\text { (years) }\end{array}$ & 73 & 19.0 & 19.0 \\
\hline $\begin{array}{c}21-26 \\
\text { (years) }\end{array}$ & 127 & 32.0 & 51.0 \\
\hline $\begin{array}{c}27-32 \\
\text { (years) }\end{array}$ & 93 & 23.7 & 74.7 \\
\hline $\begin{array}{c}\text { Over 33 } \\
\text { (years) }\end{array}$ & 99 & 25.3 & 100 \\
\hline Total & 392 & 100 & - \\
\hline
\end{tabular}

Table 2. represents the demographics of the respondent. between 16 and 20 years old have a 19\%. We have 32\% for those between 21 and 26 years old. Those between 27-32 years account for $23.7 \%$. Those above 33 years of age were $25.3 \%$. This indicates that most $(32 \%)$ of the subscribers to Mobile Number Portability (MNP) are between the ages of 21 and 26 years inclusive.

Table 3. Current Network Choice of Respondents

\begin{tabular}{|c|c|c|c|}
\hline Network & Frequency & Percentage & $\begin{array}{c}\text { Cumulative } \\
\text { percentage (\%) }\end{array}$ \\
\hline Etisalat & 42 & 11.0 & 11.0 \\
\hline Glo & 91 & 23.0 & 34.0 \\
\hline MTN & 212 & 54.0 & 88.0 \\
\hline Airtel & 47 & 12.0 & 100 \\
\hline Total & 392 & 100 & - \\
\hline
\end{tabular}

The table 3. above shows that $212(54 \%)$ of the respondents are using MTN at the moment the investigation was carried out, $91(23 \%)$ are using Glo, $47(12 \%)$ are using Airtel, while $42(11 \%)$ are using Etisalat.

Table 4. Level of Network Congestion and Call Drop

\begin{tabular}{|c|c|c|c|c|}
\hline $\begin{array}{c}\text { Netw } \\
\text { ork }\end{array}$ & $\begin{array}{c}\text { Experience } \\
\text { network } \\
\text { congestion \& } \\
\text { call drop } \\
\text { regularly } \\
\text { Frequency }\end{array}$ & $\%$ & $\begin{array}{c}\text { Experience } \\
\text { Network } \\
\text { congestion } \\
\text { \& call drop } \\
\text { not so often } \\
\text { Frequency }\end{array}$ & $\%$ \\
\hline $\begin{array}{c}\text { Etisal } \\
\text { at }\end{array}$ & 42 & 19.0 & 26 & 32.5 \\
\hline Glo & 8 & 3.6 & 24 & 30 \\
\hline MTN & 149 & 67.1 & 8 & 10 \\
\hline Airtel & 23 & 10.4 & 22 & 27.5 \\
\hline Total & 222 & 100 & 80 & 100 \\
\hline
\end{tabular}

From table 4 . it can be deduce that the majority of the respondents $302(73.5 \%)$ experience network congestion and call drop regularly, while $80(20.5 \%)$ expressed that they experience network congestion and call drop not so often. 
Table 5. Knowledge of Mobile Number Porting (MNP)

\begin{tabular}{|c|c|c|c|c|c|c|}
\hline $\begin{array}{c}\text { Net } \\
\text { work }\end{array}$ & $\begin{array}{c}\text { Frequ } \\
\text { ency } \\
\text { (Yes) }\end{array}$ & $\begin{array}{c}\text { Perce } \\
\text { ntage }\end{array}$ & $\begin{array}{c}\text { Frequ } \\
\text { ency } \\
\text { (No) }\end{array}$ & $\begin{array}{c}\text { Perce } \\
\text { ntage }\end{array}$ & $\begin{array}{c}\text { Frequ } \\
\text { ency } \\
\text { (Not } \\
\text { Sure) }\end{array}$ & $\begin{array}{c}\text { Perce } \\
\text { ntage }\end{array}$ \\
\hline $\begin{array}{c}\text { Etisa } \\
\text { lat }\end{array}$ & 26 & 12.6 & 18 & 13.7 & 8 & 14.6 \\
\hline Glo & 59 & 28.6 & 32 & 24.4 & 16 & 29.1 \\
\hline $\begin{array}{c}\text { MT } \\
\text { N }\end{array}$ & 93 & 45.2 & 74 & 56.5 & 28 & 51.0 \\
\hline $\begin{array}{c}\text { Airte } \\
1\end{array}$ & 28 & 13.6 & 7 & 5.3 & 3 & 5.5 \\
\hline $\begin{array}{c}\text { Tota } \\
1\end{array}$ & 206 & 100 & 131 & 100 & 55 & 100 \\
\hline
\end{tabular}

Based on finding from table 5. we can deduce that $52.6 \%$ of the respondents know the procedure to be followed for mobile number portability, $14 \%$ are not sure, while $33.4 \%$ said they don't know.

Table 6. Network of Respondents before number porting *67 responses were invalid here due to multiple ticking.

\begin{tabular}{|c|c|c|c|}
\hline Network & Frequency & Percentage & $\begin{array}{c}\text { Cumulative } \\
\text { percentage }(\%)\end{array}$ \\
\hline Etisalat & 44 & 14.0 & 14.0 \\
\hline Glo & 50 & 15.0 & 29.0 \\
\hline MTN & 141 & 43.0 & 72.0 \\
\hline Airtel & 90 & 28.0 & 100 \\
\hline Total & $325^{*}$ & 100 & - \\
\hline
\end{tabular}

It can be deduced from table 6. that collected verified questionnaires has a $43 \%$ (141) of respondents were on the MTN network before porting, followed by $28 \%$ (90) of respondents that were on the Airtel Network and the minority was $14 \%$ (44) of respondents on the Etisalat Network.

Table 7. Network of Respondents after porting *43 responses were invalid here due to multiple ticking.

\begin{tabular}{|c|c|c|c|}
\hline Network & Frequency & Percentage & $\begin{array}{c}\text { Cumulative } \\
\text { percentage }(\%)\end{array}$ \\
\hline Etisalat & 42 & 12.0 & 12.0 \\
\hline Glo & 131 & 38.0 & 50.0 \\
\hline MTN & 123 & 35.0 & 85.0 \\
\hline Airtel & 53 & 15.0 & 100 \\
\hline Total & 349 & 100 & - \\
\hline
\end{tabular}

Table 7. shows that respondents that had the knowledge of the procedure for mobile number porting ported to different networks due to better quality of service and cheaper costs. After porting, as the table below shows, Glo network then had the majority with $131(38 \%)$ respondents, followed by MTN with $123(35 \%)$ respondents, Airtel $53(15 \%)$ and Etisalat with $42(12 \%)$ respondents.

\section{ANALYSIS AND TEST OF HYPOTHESES}

Arising from the questionnaires administered, four hypotheses were formulated. The four hypotheses were respectively tested, using Chi-square: Testing for Goodness of Fit.
$\mathbf{H}_{\mathbf{1}}$ : There is no significant impact of perceived switching barriers on mobile number portability scheme among mobile users.

$\mathbf{H}_{2}$ : There is no significant impact of perceived service fairness on mobile number portability scheme among mobile users.

$\mathbf{H}_{3}$ : There is no significant impact of experiences with current service provider on mobile number portability scheme among mobile users.

$\mathbf{H}_{\mathbf{4}}$ : There is no significant impact of social influence on mobile number portability scheme among mobile users.

\subsection{Hypotheses Interpretation Towards Statistic Adopted}

The Chi-square Test was adopted for this research since it has been established that it is one of the suitable statistics to help us make decisions about which study outcomes reflects some differences between mobile phone users perception and their behavior related to Mobile Number Portability [6]. This reflects true differences of the underlying MNP technology and its impact in the telephony ecosystem in south west Nigeria. Also making findings about accuracy of survey sample in reflecting characteristics of MNP from which it was drawn from Table 1 . to 7 .

\subsection{Fact Finding on Chi-Square}

The null hypothesis states that there is no significant difference between the expected and observed frequencies while the alternative hypothesis states they are different [6], as a result, in this paper, the level of significance using chisquare is set at $\mathbf{. 0 5}$ which is the standard for most scientific experiments. The chi-square formula used on these data is stated below:

$\mathbf{X}^{2}=(\mathbf{O}-\mathbf{E})^{2} / \mathbf{E}$

Where $O$ is the Observed Frequency in each category

$\mathrm{E}$ is the Expected Frequency in the

corresponding category

df is the "degree of freedom" $(n-1)$

\section{$\mathrm{X}^{2}$ is Chi-Square}

\subsection{The First Hypothesis $\left(\mathrm{H}_{1}\right)$}

The first $\left(\mathbf{H}_{\mathbf{1}}\right)$ state that there is no significant impact of perceived switching barriers on mobile number portability scheme among mobile users. This was tested with combination of six tables' entry as follows: Table 2. 3. 4. 5. 6 . and 7. respectively. By following the procedures on chisquare goodness-of-fit tests, we have as follows: 
Table 8 Observed frequencies $(O)$

\begin{tabular}{|c|c|c|c|c|c|c|c|c|c|c|c|c|c|}
\hline 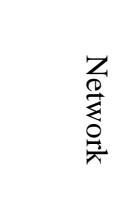 & 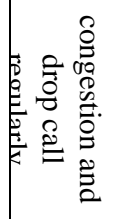 & 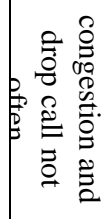 & 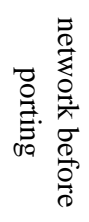 & 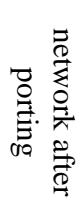 & $\begin{array}{l}3 \overline{0} \\
z \\
0 \\
0 \\
0 \\
0 \\
0 \\
0 \\
0 \\
0 \\
0 \\
0 \\
0\end{array}$ & 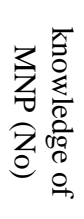 & 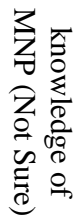 & 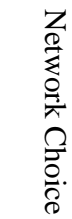 & 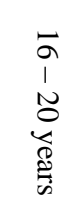 & 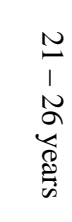 & 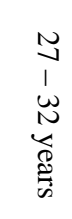 & 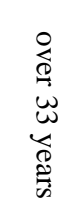 & $\begin{array}{l}0 \\
\stackrel{0}{0} \\
\stackrel{0}{0} \\
\overrightarrow{0} \\
\stackrel{0}{D}\end{array}$ \\
\hline Estisalat & 42 & 26 & 44 & 42 & 26 & 18 & 8 & 42 & 8 & 14 & 9 & 11 & 290 \\
\hline Glo & 8 & 24 & 50 & 131 & 59 & 32 & 16 & 91 & 21 & 34 & 15 & 21 & 592 \\
\hline MTN & 149 & 8 & 141 & 123 & 93 & 74 & 28 & 212 & 28 & 76 & 61 & 47 & 1040 \\
\hline Airtel & 23 & 22 & 90 & 53 & 28 & 7 & 3 & 47 & 16 & 3 & 8 & 20 & 320 \\
\hline Total & 312 & 80 & 325 & 349 & 206 & 131 & 55 & 392 & 73 & 127 & 93 & 99 & 2242 \\
\hline
\end{tabular}

Table 9 Expected frequencies (E)

Hence to get the entire table expectation entry we calculate (row total multiply column total) divide overall total

\begin{tabular}{|c|c|c|c|c|c|c|c|c|c|c|c|c|c|}
\hline $\begin{array}{l}Z Z \\
\frac{Z}{0} \\
\frac{\pi}{\pi} \\
O \\
\frac{Z}{\pi}\end{array}$ & 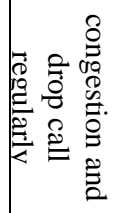 & 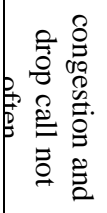 & 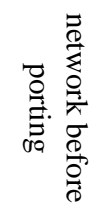 & 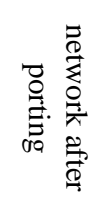 & 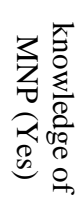 & 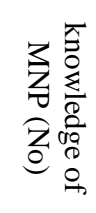 & 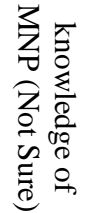 & 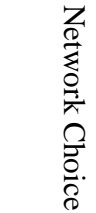 & $\begin{array}{l}\vec{a} \\
i \\
\tilde{o} \\
\stackrel{0}{0} \\
\stackrel{0}{*}\end{array}$ & 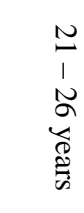 & 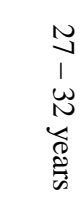 & 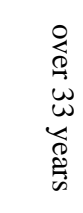 & 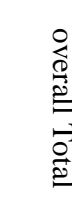 \\
\hline Estisalat & 40.36 & 10.35 & 42.04 & 45.14 & 26.65 & 16.94 & 7.11 & 50.70 & 9.44 & 16.43 & 12.03 & 12.81 & 290 \\
\hline Glo & 82.38 & 21.12 & 85.82 & 92.15 & 54.39 & 34.60 & 14.52 & 103.51 & 19.28 & 33.53 & 24.56 & 26.14 & 502 \\
\hline MTN & 144.73 & 37.11 & 150.76 & 161.89 & 95.56 & 60.77 & 25.51 & 181.84 & 33.86 & 58.91 & 43.14 & 45.92 & 1040 \\
\hline Airtel & 44.53 & 11.42 & 46.37 & 49.81 & 29.40 & 18.70 & 7.85 & 55.95 & 10.42 & 18.13 & 13.27 & 14.13 & 320 \\
\hline Total & 222 & 80 & 324.99 & 348.99 & 206 & 131.01 & 54.99 & 392 & 73 & 127 & 93 & 99 & 2242 \\
\hline
\end{tabular}

\subsubsection{Find the $d f .(N-1)$}

The number of degree of freedom is calculated from $M * N$ which is $(\mathrm{M} * \mathrm{~N}-1)$; so in this case we have $(12 * 4-1)=48$ $-1=47$; hence the degree of freedom is 47 .

\subsubsection{Find the table value (consult the Chi Square Table)}

Hence the tabular $95 \%$ value of $X^{\wedge} 2($ degree of freedom $=47)$ is 64.001; the calculated chi-square value for the set of data as analyzed is 200.8977 , which is significant at $5 \%$ level and greater than the table critical value 64.001. The null hypothesis is rejected and the alternate hypothesis is accepted (there is a significant difference). In this situation, there is significant impact of perceived switching barriers on mobile number portability scheme among mobile users. So we can deduce that our survey sample does not support the hypothesis of $\mathbf{H}_{\mathbf{1}}$.

\subsection{Test of Hypothesis $\left(\mathrm{H}_{2}\right)$ Results and Interpretation}

$\mathbf{H}_{2}$ : There is no significant impact of perceived service fairness on mobile number portability scheme among mobile users. This was tested with combination of four tables' entry as follows: Table 2.3.5. and 6. respectively. By following the procedures on chi-square goodness-of-fit tests, we have as follows:

\section{Table 10. Observed frequencies $(\mathrm{O})$ in $\mathrm{H}_{2}$}

\begin{tabular}{|l|l|l|l|l|l|l|l|l|l|l|}
\hline $\begin{array}{l}\text { Networ } \\
\mathrm{k}\end{array}$ & $\begin{array}{l}16 \\
20 \\
\text { years }\end{array}$ & $\begin{array}{l}21- \\
26 \\
\text { years }\end{array}$ & $\begin{array}{l}27- \\
32 \\
\text { years }\end{array}$ & $\begin{array}{l}\text { over } \\
33 \\
\text { years }\end{array}$ & $\begin{array}{l}\text { network } \\
\text { after } \\
\text { porting }\end{array}$ & $\begin{array}{l}\text { knowledge } \\
\text { of MNP } \\
\text { (Yes) }\end{array}$ & $\begin{array}{l}\text { knowledg } \\
\text { e of MNP } \\
\text { (No) }\end{array}$ & $\begin{array}{l}\text { knowledge } \\
\text { of MNP } \\
\text { (Not Sure) }\end{array}$ & $\begin{array}{l}\text { Network } \\
\text { Choice }\end{array}$ & overall Total \\
\hline $\begin{array}{l}\text { Estisala } \\
\mathrm{t}\end{array}$ & 8 & 14 & 9 & 11 & 42 & 26 & 18 & 8 & 42 & 178 \\
\hline Glo & 21 & 34 & 15 & 21 & 131 & 59 & 32 & 16 & 91 & 420 \\
\hline MTN & 28 & 76 & 61 & 47 & 123 & 93 & 74 & 28 & 212 & 742 \\
\hline Airtel & 16 & 3 & 8 & 20 & 53 & 28 & 7 & 3 & 47 & 185 \\
\hline Total & 73 & 127 & 93 & 99 & 349 & 206 & 131 & 55 & 392 & 1525 \\
\hline
\end{tabular}


Table 11. Expected frequencies $(\mathrm{E})$ in $\mathrm{H}_{2}$

Hence to get the entire table expectation entry we calculate (row total multiply column total) divide overall total

\begin{tabular}{|l|l|l|l|l|l|l|l|l|l|l|}
\hline $\begin{array}{l}\text { Networ } \\
\mathrm{k}\end{array}$ & $\begin{array}{l}16 \\
20 \\
\text { years }\end{array}$ & $\begin{array}{l}21- \\
26 \\
\text { years }\end{array}$ & $\begin{array}{l}27- \\
32 \\
\text { years }\end{array}$ & $\begin{array}{l}\text { over } \\
33 \\
\text { years }\end{array}$ & $\begin{array}{l}\text { network } \\
\text { after } \\
\text { porting }\end{array}$ & $\begin{array}{l}\text { knowledge } \\
\text { of MNP } \\
\text { (Yes) }\end{array}$ & $\begin{array}{l}\text { knowledg } \\
\text { e of MNP } \\
\text { (No) }\end{array}$ & $\begin{array}{l}\text { knowledge } \\
\text { of MNP } \\
\text { (Not Sure) }\end{array}$ & $\begin{array}{l}\text { Network } \\
\text { Choice }\end{array}$ & overall Total \\
\hline $\begin{array}{l}\text { Estisala } \\
\mathrm{t}\end{array}$ & 8.52 & 14.82 & 10.86 & 11.56 & 40.74 & 24.04 & 15.29 & 6.42 & 45.75 & 178 \\
\hline Glo & 20.10 & 34.98 & 25.61 & 27.27 & 96.12 & 56.73 & 36.08 & 15.15 & 107.96 & 420 \\
\hline MTN & 35.52 & 61.79 & 45.25 & 48.17 & 169.81 & 100.23 & 63.74 & 26.76 & 190.73 & 742 \\
\hline Airtel & 8.86 & 15.14 & 11.28 & 12.01 & 42.34 & 24.99 & 15.89 & 6.67 & 47.55 & 185 \\
\hline Total & 73 & 127 & 93 & 99.01 & 349.01 & 205.99 & 131 & 55 & 391.99 & 1525 \\
\hline
\end{tabular}

\subsubsection{Find the $d f .(N-1)$}

The number of degree of freedom is calculated from $\mathrm{M} * \mathrm{~N}$ which is $\mathrm{M} * \mathrm{~N}-1$; so in this case we have $(9 * 4-1)=36-$ $1=35$; hence the degree of freedom is 35 .

\subsection{2: Find the table value (consult the Chi Square Table)}

Hence the tabular $95 \%$ value of $X^{\wedge} 2($ degree of freedom $=35)$ is 49.802; the calculated chi-square value for the set of data as analyzed is 82.8812 and is significant at $5 \%$ level and greater than the table critical value (49.802). The null hypothesis is rejected and the alternate (there is a significant difference) is accepted. Therefore, there is significant impact of perceived service fairness on mobile number portability scheme among mobile users in the south western part of Nigeria. So we conclude that our survey sample does not support the hypothesis of $\mathbf{H}_{2}$.

\subsection{Test of Hypothesis $\left(\mathrm{H}_{3}\right)$ Results and Interpretation}

$\mathbf{H}_{3}$ : There is no significant impact of experiences with current service provider on mobile number portability scheme among mobile users. This was tested with combination of five tables' entry as follows: Table 2. 3. 4. 6 . and 7. respectively. By following the procedures on chisquare goodness-of-fit tests, we have as follows

Table 12. Observed frequencies $(\mathrm{O})$ in $\mathrm{H}_{3}$

\begin{tabular}{|l|l|l|l|l|l|l|l|l|l|l|}
\hline Network & $\begin{array}{l}16 \\
20 \\
\text { years }\end{array}$ & $\begin{array}{l}21- \\
26 \\
\text { years }\end{array}$ & $\begin{array}{l}27- \\
32 \\
\text { years }\end{array}$ & $\begin{array}{l}\text { over } \\
\text { years }\end{array}$ & $\begin{array}{l}\text { network } \\
\text { before } \\
\text { porting }\end{array}$ & $\begin{array}{l}\text { network } \\
\text { after } \\
\text { porting }\end{array}$ & $\begin{array}{l}\text { Network } \\
\text { Choice }\end{array}$ & $\begin{array}{l}\text { congestion and } \\
\text { drop congestion and } \\
\text { regularly }\end{array}$ & $\begin{array}{l}\text { overall } \\
\text { drop call not } \\
\text { often }\end{array}$ & $\begin{array}{l}\text { Total } \\
\text { Estisalat }\end{array}$ \\
\hline & 14 & 9 & 11 & 44 & 42 & 42 & 42 & 26 & 238 \\
\hline Glo & 21 & 34 & 15 & 21 & 50 & 131 & 91 & 98 & 24 & 485 \\
\hline MTN & 28 & 76 & 61 & 47 & 141 & 123 & 212 & 149 & 8 & 845 \\
\hline Airtel & 16 & 3 & 8 & 20 & 90 & 53 & 47 & 23 & 22 & 282 \\
\hline Total & 73 & 127 & 93 & 99 & 325 & 349 & 392 & 312 & 80 & 1850 \\
\hline
\end{tabular}

Table 13. Expected frequencies $(\mathrm{E})$ in $\mathrm{H}_{3}$

Hence to get the entire table expectation entry we calculate (row total multiply column total) divide overall total.

\begin{tabular}{|l|l|l|l|l|l|l|l|l|l|l|}
\hline Network & $\begin{array}{l}16 \\
20 \\
\text { years }\end{array}$ & $\begin{array}{l}21- \\
26 \\
\text { years }\end{array}$ & $\begin{array}{l}27- \\
32 \\
\text { years }\end{array}$ & $\begin{array}{l}\text { over } \\
33 \\
\text { years }\end{array}$ & $\begin{array}{l}\text { network } \\
\text { before } \\
\text { porting }\end{array}$ & $\begin{array}{l}\text { network } \\
\text { after } \\
\text { porting }\end{array}$ & $\begin{array}{l}\text { Network } \\
\text { Choice }\end{array}$ & $\begin{array}{l}\text { congestion and } \\
\text { drop congestion and } \\
\text { regularly }\end{array}$ & $\begin{array}{l}\text { overall } \\
\text { drop call not } \\
\text { often }\end{array}$ & Total \\
Estisalat & 9.39 & 16.34 & 11.96 & 12.74 & 41.81 & 44.90 & 50.43 & 40.14 & 10.29 & 238 \\
\hline Glo & 19.14 & 33.29 & 24.38 & 25.95 & 85.20 & 91.49 & 102.77 & 81.79 & 20.97 & 485 \\
\hline MTN & 33.34 & 58.01 & 42.48 & 45.22 & 148.45 & 159.41 & 179.05 & 142.51 & 36.54 & 845 \\
\hline Airtel & 11.13 & 19.36 & 14.18 & 14.18 & 49.54 & 53.20 & 59.75 & 47.56 & 12.19 & 282 \\
\hline Total & 73 & 127 & 93 & 99 & 325 & 349 & 392 & 312 & 79.92 & 1850 \\
\hline
\end{tabular}

\subsubsection{Find the $d f .(N-1)$}

The number of degree of freedom is calculated from $\mathrm{M} * \mathrm{~N}$ which is $\mathrm{M} * \mathrm{~N}-1$; so in this case we have $(9 * 4-1)=36-$ $1=35$; hence the degree of freedom is 35 .

\subsubsection{Find the table value (consult the Chi Square Table)}

Hence the tabular $95 \%$ value of $X^{\wedge} 2($ degree of freedom $=35)$ is 49.802 ; the calculated chi-square value for the set of data as analyzed is 182.8179 and is significant at $5 \%$ level and greater than the table critical value 49.802 . The null hypothesis is rejected and the alternate hypothesis (there is a significant difference) is accepted. Hence there is significant impact of experiences with current service provider on mobile number portability scheme among mobile users in the south western part of Nigeria. So we conclude that our survey sample still does not support the hypothesis of $\mathbf{H}_{3}$. 


\subsection{Test of Hypothesis $\left(\mathrm{H}_{4}\right)$ Results and Interpretation}

$\mathbf{H}_{\mathbf{4}}$ : There is no significant impact of social influence on mobile number portability scheme among mobile users. This was tested with combination of five tables' entry as follows: Table 1. 2. 5. 6. and 7. respectively. By following the procedures on chi-square goodness-of-fit tests, we have as follows:

Table 14. Observed frequencies $(\mathrm{O})$ in $\mathrm{H}_{4}$

\begin{tabular}{|c|c|c|c|c|c|c|c|c|c|c|c|c|}
\hline $\begin{array}{l}\frac{y}{0} \\
\vdots \\
\text { z }\end{array}$ & 离 & 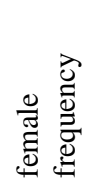 & 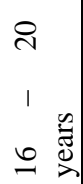 & 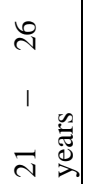 & 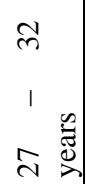 & 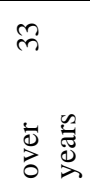 & 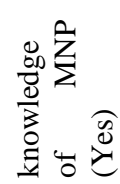 & 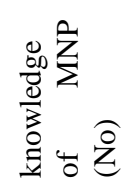 & 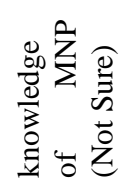 & 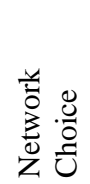 & 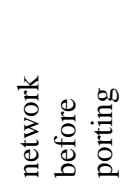 & 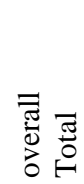 \\
\hline $\begin{array}{l}\text { Estisala } \\
\mathrm{t}\end{array}$ & 35 & 26 & 8 & 14 & 9 & 11 & 26 & 18 & 8 & 42 & 44 & 241 \\
\hline Glo & 39 & 47 & 21 & 34 & 15 & 21 & 59 & 32 & 16 & 91 & 50 & 425 \\
\hline MTN & 66 & 115 & 28 & 76 & 61 & 47 & 93 & 74 & 28 & 212 & 141 & 941 \\
\hline Airtel & 30 & 19 & 16 & 3 & 8 & 20 & 28 & 7 & 3 & 47 & 90 & 271 \\
\hline Total & 170 & 207 & 73 & 127 & 93 & 99 & 206 & 131 & 55 & 392 & 325 & 1878 \\
\hline
\end{tabular}

Table 15. Expected frequencies (E) in $\mathbf{H}_{4}$

Hence to get the entire table expectation entry we calculate (row total multiply column total) divide overall total

\begin{tabular}{|c|c|c|c|c|c|c|c|c|c|c|c|c|}
\hline $\begin{array}{l}\frac{y}{0} \\
3 \\
z \\
z\end{array}$ & 莺 & 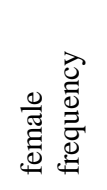 & 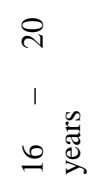 & 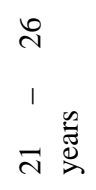 & $\begin{array}{l}\approx \\
1 \\
\approx \stackrel{\Xi}{\approx}\end{array}$ & 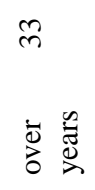 & 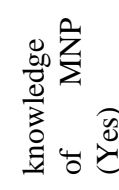 & 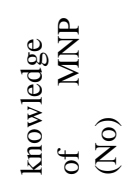 & 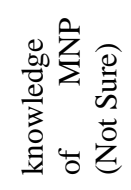 & 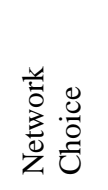 & 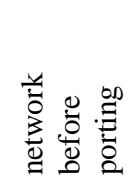 & 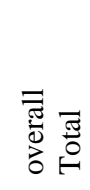 \\
\hline $\begin{array}{l}\text { Estisala } \\
\mathrm{t}\end{array}$ & 21.82 & 26.56 & 9.37 & 16.30 & 11.93 & 12.70 & 26.43 & 16.81 & 7.06 & 50.30 & 41.71 & 241 \\
\hline Glo & 38.47 & 46.85 & 16.52 & 28.74 & 21.05 & 22.40 & 46.62 & 29.65 & 12.45 & 88.71 & 73.55 & 425 \\
\hline MTN & 85.18 & 103.72 & 36.58 & 63.64 & 46.60 & 49.61 & 103.22 & 65.64 & 22.56 & 196.42 & 162.85 & 941 \\
\hline Airtel & 24.53 & 29.87 & 10.53 & 18.32 & 13.42 & 14.29 & 29.73 & 18.90 & 7.94 & 56.57 & 46.90 & 271 \\
\hline Total & 170 & 207 & 73 & 127 & 93 & 99 & 206 & 131 & 55.01 & 392 & 325.01 & 1878 \\
\hline
\end{tabular}

\subsubsection{Find the $d f .(N-1)$}

The number of degree of freedom is calculated from an $\mathrm{M} * \mathrm{~N}$ which is $\mathrm{M} * \mathrm{~N}-1$; so in this case we have $(11 * 4-1)=44$ $-1=43$; hence the degree of freedom is 43 .

\subsubsection{Find the table value (consult the Chi Square \\ Table)}

Hence the tabular $95 \%$ value of $X^{\wedge} 2($ degree of freedom $=43)$ is 59.304; the calculated chi-square value for the set of data as analyzed is 125.13072 and is significant at $5 \%$ level and greater than the table critical value 59.304. The null hypothesis is rejected and the alternate hypothesis (there is a significant difference) is accepted. This shows that there is significant impact of social influence on mobile number portability scheme among mobile users. So we conclude that our survey sample supports the hypothesis of $\mathbf{H}_{\mathbf{4}}$.

\section{Conclusion}

This study has shown that there is no significant impact of mobile number portability scheme among users. As at present this is attributed to the fear of the subscribers that no network out performs another. This perspective is subject to change if operators improve on the quality of service and reduce tariff rate of their network. Mobile Number portability has come to stay in Nigeria but not all the subscribers have keyed into it.

\section{RECOMMENDATIONS}

Nigeria Communications Commission (NCC) should have a good synergy with the Number Portability Control (NPC) to allow monitoring and generating reports to assess progress trends. This is because in extremely dynamic and competitive markets, it is important for the regulator to monitor and control the Number Portability (NP) processes for the good of the general consumers.

\section{REFERENCES}

[1] LIN Yi-Bing, CHLAMTAC Imrich, YU Hsiao-Cheng. IEEE Network - NETWORK, vol. 17, no. 5, pp. 8-16, 2003

[2] Information paper: MNP in Singapore, Infocomm Development Authority of Singapore, August 2003

[3] INTUG (2003), Mobile Number Portability, International Telecommunications User Group (INTUG): [www.intug.net/mnp

[4] Saltzman, Marc. "'Wireless number portability' arrives in Canada. Sympatico MSN. Retrieved April 4, 2008

[5] Atiya Faiz Khan. Mobile Number Portability: Challenges and Solutions. 2010-11.

[6] DiMaria, R. Ann (2013), "Understanding and Interpreting the Chi-Square Statistic", retrieved from 
URLs:http:/hsc.wvu.edu/Charleston/son/Class2chisquare DiMaria.pdf on $27^{\text {th }}$ August, 2013.

[7] Shin, D. \& Kim, W. (2007). Mobile number portability on customer switching behavior: in the case of the Korean mobile

[8] Juwah, E .(2009), "Office of the Executive ViceChairman/CEO Nigerian Communications Commission"Implementation of Mobile Number Portability in Nigeria.
[9] Voice and Data (May 2009): Mobile Number Portability - Poaching with Portability

[10] William C. Y Lee, Wireless and Cellular Telecommunications, 2006.

[11] Stefan Buehler, Ralf Dewenter, Justus Haucap. Mobile Number Portability in Europe. 